\title{
The impact of the Bible and Bible themes on John Rangiah's Ministry in South Africa
}

\author{
Author: \\ Rodney Ragwan ${ }^{1}$ \\ Affiliation: \\ ${ }^{1}$ Department of Church \\ History and Church Polity, \\ University of Pretoria, \\ South Africa \\ Correspondence to: \\ Rodney Ragwan \\ Email: \\ rragwan@eastern.edu \\ Postal address: \\ 250 Congress Avenue, \\ Lansdowne, PA 19050, USA \\ Dates: \\ Received: 06 July 2011 \\ Accepted: 23 Sept. 2011 \\ Published: 24 Feb. 2012 \\ How to cite this article: \\ Ragwan, R., 2012, 'The \\ impact of the Bible and Bible \\ themes on John Rangiah's \\ Ministry in South Africa', \\ Verbum et Ecclesia 33(1), \\ Art. \#415, 7 pages. http:// \\ dx.doi.org/10.4102/ \\ ve.v33i1.415
}

(C) 2012. The Authors. Licensee: AOSIS OpenJournals. This work is licensed under the Creative Commons Attribution License.
John Rangiah was the first Indian Baptist missionary who came to Natal (today called KwaZuluNatal). He was born in India in 1866 and died in 1915. He established the first Telugu Baptist Church on the African continent in Kearsney, Natal. In the corpus of South African Baptist mission literature, the contribution of John Rangiah is given very little attention. Although he is referenced by Baptist historians for his work amongst Indian Baptists, the impact of the Bible and Bible themes as well as his theology in South Africa have not been examined. This article provides insight into Rangiah's early life and faith, and critically examines his understanding of the Bible and its themes, such as the Bible, prayer, salvation and eschatological hope. These themes will be critically examined from a conservative evangelical perspective and thereafter attempts to examine these using elements of post-colonial hermeneutics will be undertaken.

\section{Rangiah's early life and faith}

In 1835 the American Baptist Foreign Missionary Society sent Reverend Samuel Day and his wife as missionaries to India to work amongst the Telugus with others following later. John Rangiah who was born in India was influenced by these American missionaries. In 1903 at the age of 37 he came to South Africa as the first Indian Baptist missionary of the Telugu Baptist Home Missionary Society.

Finette Jewett (1898:49) wrote about John Rangiah's father's eagerness to receive education at one of the schools established by the American Baptist Foreign Missionary Society. John Rangiah's father, Tupili Rangiah, would consistently arrive at the American Baptist School in Nellore requesting the opportunity to learn. The Lymans, who were American Baptist missionaries, granted this request and recognised that $\mathrm{T}$. Rangiah was a very diligent student. As a consequence, he was employed as a student tutor to others at the school. During his association with the American Baptist missionaries in Nellore, T. Rangiah converted to Christianity and later became the pastor of the Madras Baptist Church. T. Rangiah had four sons, one of whom was John Rangiah, and all of them were ministers.

There are no records of who was responsible for John Rangiah's conversion. This experience is shrouded in mystery but the American Baptists were probably instrumental in his conversion. However, Rangiah (1905:1) states that in the then Madras Presidency the Christians owed their conversion to the work of the American and Canadian missions. It seems that John spent much of his boyhood around American Baptist missionaries. As a young man he took an active part in Christian ministry. He served as a Sunday school teacher, Sunday school superintendent, lay preacher, evangelist, treasurer and deacon. Rangiah also served as headmaster of the Nellore Boy's School from 1897 to 1900 and of the Nellore Girl's School from 1901 to 1903. On 20 April 1903, he was ordained as a minister of the Lone Star Baptist Church (Rangiah 1953:10).

Mrs. Lyman Jewett (1913:1-6) wrote an article in a journal, entitled "John Rangiah, The First Telugu Foreign Missionary", in which she records the life of Rangiah whilst in India and his work in South Africa. She provides a background of Rangiah's parents and their conversion to Christianity. Lyman describes Rangiah's commitment to the Christian faith, and more specifically, to his personal life. She wrote (1913:4) about Rangiah's prayer request which he shared at his ordination service. He requested that the audience pray that he would not be proud, as he was the first foreign Telugu missionary and so many kind words were spoken of him. Lyman further refers to the positive comments of two important leaders about Rangiah's work in South Africa. One is of David Downie and the other is a response from Dr McLaurin, a professor at the Ramapatam Seminary in India. Dr McLaurin shared the good work of Rangiah's ministry in South Africa, stating that it has given a mighty impetus to the revival spirit in the seminary at Ramapatnam, and that they will extend it, if possible, into every church. 
The request for a missionary was received from South Africa for a Telugu speaking minister. Reverend John Rangiah, after much prayer, accepted this invitation. On 24 January 1903, he had a vision where he saw two angels who comforted him with the words, 'We have been praying to the Lord for the past few years ... that He may send a Telugu preacher and today He has provided one for us' (Rangiah 1953:9). The angels then handed him Bibles. Rangiah describes this experience as 'glorious'. He was greatly encouraged by this experience (Rangiah 1953:9).

In 1903 Rangiah, his wife and two children left India for South Africa to work amongst the indentured labourers. In that same year he established the first Telugu Indian Baptist Church in Africa; he established eight churches in total. In 1914 he formed the Baptist Association of South Africa. As a missionary, Rangiah made significant strides. He was the first foreign Telugu Indian missionary of the American Baptist Church Society's mission church (Stanley 2009:100). Rangiah also established the first Indian Baptist Church in South Africa (Rangiah 1953:15). Missions in South Africa were carried out by mission agencies from Europe. Rangiah's mission organisation (now called the Baptist Association of South Africa) with the exception of the Swedish Mission in South Africa, was the only mission in the country that was established by Indians from India and not by Europeans.

His work still continues today and has become an important organisation in KwaZulu-Natal. It is regrettable that South African Baptist historiography does not include Rangiah's theology as it is important to do so because it provides insight into the ideas of other Christian leaders at that time and thus help us to understand the contributions of the church in the early 20th century in the KwaZulu-Natal region. It also helps us to understand the way Christians responded to colonialism and apartheid.

\section{The Bible}

John Rangiah's theology was influenced by a number of factors, such as context, culture and education. Rangiah received his education and lived most of his adult life in British India. In addition, Rangiah came from a colonised India to a colonised South Africa. It is against this background that one must attempt to analyse Rangiah's theology. Here, I will first discuss broadly the Bible themes and characteristics of his theology. It will include the traditional examination of this theology followed by an examination using post-colonial hermeneutics.

Rangiah's theology was eclectic in nature; he embraced elements of the Calvinist and the Arminian perspectives. Rangiah did, however, operate from a conservative evangelical paradigm.

When he decided to come to South Africa as a missionary, he realised that no human effort would convince his wife Kanakamma to agree to accompany him on such a mission. He engaged in prayer and this yielded the desired result.
He commented that 'God worked wonders' (Rangiah 1953:10). He also believed that when he first arrived in Kearsney and was in need of accommodation, it was God's intervention which resulted in Sir James Hulett's providing accommodation for him. His prayer was, 'He raiseth up the poor out of the dust and lifteth the needy out of the dunghill' (Rangiah 1953:13).

When the poor Telugus on their own accord, decided to send Rangiah as their first foreign missionary, they showed their willingness to participate in God's mission worldwide. Rangiah took the invitation to participate in that mission seriously when he and his family left India to work amongst the indentured Baptist labourers in Natal (Rangiah 1953:11).

Not only did Rangiah evidence a commitment to Christian service and mission in Natal, in 1910 he also supported, by his attendance, one of eight goals of the World Missionary Conference in Edinburgh (1910) - 'Carrying the Gospel to all the World' (Stanley 2009:49, 100).

Rangiah championed the Bible as the bedrock of his Christian life and practice. Rangiah's strong Biblicist orientation is illustrated most powerfully in the images on the letterhead that he used at the start of his ministry. On the letterhead is the name of the mission, Telugu Baptist, followed by his name, Reverend John Rangiah, and the address in Kearsney, South Africa. His letterhead has a drawing of a dove carrying a branch with the biblical text Isaiah 61:1 written below the dove:

The Spirit of the Lord God is upon me; because the Lord hath anointed me to preach good tidings unto the meek; he hath sent me to bind up the broken-hearted, to proclaim liberty to the captives, and the opening of the prison to them that are bound; To proclaim the acceptable year of the Lord, and the day of vengeance of our God; to comfort all that mourn; To appoint unto them that mourn in Zion, to give unto them beauty for ashes, the oil of joy for mourning, the garment of praise for the spirit of heaviness; that they might be called trees of righteousness, the planting of the Lord, that he might be glorified.

This text provides an insight into Rangiah's faith. In attempting to understand the relevance of this text to his faith and mission, it does seem to convey the idea that God has found favour in him and has put the Holy Spirit upon him as a seal of approval for the task of mission. He understood his task to be that of a missionary who engaged in extensive preaching. In 1903 when Rangiah arrived in South Africa he began almost immediately with his preaching ministry. Mimosthram Rangiah (1953:12) wrote that his grandfather, Reverend Rangiah, made frequent visits to Durban and preached the Gospel in many of its suburbs.

One of the more poignant examples of Rangiah's Christian compassion occurred in a conversation with a Telugu man who was a murderer. This criminal was awaiting execution when Rangiah was informed about his fate. Rangiah provided spiritual support for him and even pleaded with the Governor of Natal to spare the man's life, but he was unsuccessful (Rangiah 1953:12). 
After the condemned man responded favourably to Rangiah's counsel and indicated that he was ready to accept the Christian faith, Rangiah read a text from 2 Corinthians 4:7: 'But we have this treasure in earthen vessels, that the excellency of the power may be of God, and not of us'. It appeared that Rangiah was explaining to the condemned man that his body was a fragile container that held his soul and that through God's power the gospel is now in him (that earthen vessel). It was indeed an appropriate encouragement to the brokenhearted man. Before the execution, the man gave a speech in which he repented his crime and described how the Christian faith had transformed his life (Rangiah 1953:12).

Another line in the text found on Rangiah's letterhead also provides an insight to his passion for his fellow Telugus. It reads, '... to proclaim liberty to the captives, and the opening of the prison to them that are bound'. He believed that many of these Telugus were in need of spiritual freedom but it may not have been limited to this.

Right from the beginning of his time in South Africa Rangiah was an avid reader of the Bible. It is recorded that when the ship he was travelling on from India to Durban, the Safari, docked at 18:00 at the Durban harbour, the passengers had to remain on board overnight until the next morning before disembarking. During this time Rangiah spent time reading the Bible, in particular the Acts of the Apostles (Rangiah 1953:11). In addition, at the conclusion of Rangiah's report of the Telugu Baptist Mission to the Telugu Baptist Home Missionary Society, he quotes (Rangiah 1905:5) a very significant biblical text from Malachi 3:10-12: 'All nations shall call you blessed; for ye shall be a delightsome land, saith the Lord of Hosts'.

It is not easy to clearly define Rangiah's theological orientation based on his ministry in South Africa because the Indian Baptist Church did not label people according to different theological persuasions. Furthermore, the vast majority of the indentured labourers were illiterate (Rangiah 1953:16). However, because American Baptists influenced Rangiah's theological education background, he worked mainly out of their paradigm which emphasised the sovereignty of God, the kingdom of God and the church. There is much debate in Christendom about the sovereignty of God regarding salvation. There is the Calvinistic and the Arminian views. Both of these views take into account the sovereignty of God but there is a divergent view with regard to the definition of the sovereignty of God pertaining to salvation. For Calvinists, the sovereignty of God is a cardinal aspect in their understanding of salvation. According to this understanding (Birch 2008:1), God has the right to elect one person to be saved and reprobate another. The Arminian view maintains that humanity has a free will with regard to their salvation. Both views are compelling. Rangiah's approach to salvation reflects an Arminian orientation. His very first ministry assignment was to a prisoner called Subbadoo. Rangiah feared that Subbadoo would harden his heart towards God but was later pleased that Subbadoo made a decision to accept the Christian faith (Rangiah 1953:12). In the twelve years that Rangiah worked in Natal, his hymns (Rangiah 1905:1) featured the theme of salvation. He travelled widely holding evangelistic services at Kearsney, Durban, Darnall, Amatikulu, Tinley Manor, Stanger, Verulam, Pietermaritzburg, Dundee and Glendale where he reported of persons responding to the gospel and that they made decisions to receive salvation (Rangiah 1953:17-27).

The adventurous spirit and trusting faith of men like Paul the apostle became very evident in the life and ministry of Rangiah. Like Paul the apostle, Rangiah travelled on missionary assignments planting churches, training and mentoring leaders for ministry. In examining Rangiah's work amongst the Telugus in Natal, the following Bible themes are reflected in his ministry: prayer, salvation and eschatological hope.

Rangiah began his ministry in his native country, India, and continued this in his adopted country, South Africa. Both these countries were colonised; the question is, did his ministry, as informed by his theology, address the issues faced by his congregants? There is no doubt that his ministry impacted the lives of the Indian Baptist Indentured labourers. However, it is important to examine critically the impact of the Bible and Bible themes on his ministry in Natal and its influence on his ministry. I begin by discussing briefly important aspects of post-colonial biblical interpretation and then I examine how Rangiah's ministry was informed by his reading of the Bible.

Rangiah's early years were spent with American Baptists in India. These American Baptist missionaries were part of a strong denomination that had its evangelical roots in England. Rangiah was schooled in evangelical theology in India at a school started by American Baptist missionaries. However, he largely employed this theology in his work in South Africa. His understanding and interpretation of the Bible must be seen against his early association with and schooling in an American Baptist theological institution. Rangiah's ministry was influenced by American Baptists in India. American Baptists have a distinct denominational identity. They are a biblically based people whose life and witness are grounded in the Scriptures which revolve around an evangelical centre. Broadly, the American Baptist missionaries' theology centred on God's sovereignty in which the theology of the Kingdom and the church feature strongly. Rangiah can be best described as a moderate evangelical but sometimes leaning more towards a conservative orientation.

Roger Olson (1998) mentions the core characteristics of authentic evangelical theology:

- The Bible is the supreme norm of truth for Christian belief and practices and that the Biblical message is enshrined in its interpretation of those narratives.

- A supernatural worldview that is centered in a transcendent personal God who interacts with, and intervenes in creation. 
- The forgiving and transforming grace of God through Jesus Christ in the experience called conversion. This experience is the centre of authentic Christian experience.

- The primary task of Christian theology is to serve the Christian Church's mission of bringing God's grace to the whole world through proclamation and service.

Rangiah worked out of this evangelical paradigm. However, there are features within his evangelical theology which place him more on the conservative side theologically. For instance, except for the establishment of a school for the Telugu children in Kearsney, he concentrated largely on evangelism and very little on social issues.

In preparing leaders and congregants, Rangiah believed that the Bible was critical in shaping their lives. He held Bible classes at Kearsney where he chose the lives of Biblical characters such as Joseph, Samson and Ruth as models for the male and female leaders and congregants (Rangiah 1953:18).

\section{Prayer}

Rangiah believed and maintained that prayer was an important spiritual discipline and practice; prayer featured prominently in his reports as well. In 1902, when Rangiah was initially challenged about responding to a request to go to South Africa to work amongst the Telugu Christians, he went down on his knees and prayed for God's will to be done (Rangiah 1953:8). This was a simple act of submission to God; prayer and submission to God became the hallmarks of his work as a missionary.

In preparation for his ministry in South Africa, Rangiah spent three months in prayer (Rangiah 1953:8). Even when his wife, Kanakamma resisted the idea of them coming to Natal to take up the mission work, Rangiah spent time in fasting and prayer. His prayer was:

O Lord grant if it is thy will that we should labour in Natal for Thee, open Thou the way. Grant Kanakamma courage, O Lord, that she may be able to leave her beloved parents and friends and undertake the journey with me. Do tell us, O Lord, whether to leave behind these my two children or to take them with me. If it is Thy will that we leave them behind, grant Kanakamma and me that courage to endure the pangs of separation. Help us on our voyage and use us for Thy glory and service. (Rangiah 1953:9)

This prayer reflected a person's deep concern for his family and ministry. Rangiah recognised the spiritual resource that is available within the Christian faith particularly in a text in Proverbs 3:6 which states, 'Commit to the Lord whatever you do, and your plans will succeed'. It does indicate an understanding of the supremacy of God in matters of family and ministry and that God must direct these matters. Rangiah's prayer was answered within six weeks. His wife informed him that she was ready to come to Natal and that there should be no delay (Rangiah 1953:10).

In 1903, when Rangiah arrived at Port Natal, he was so overwhelmed by the task that was before him. He prayed for God's strength and grace (Rangiah 1953:11). When
Rangiah arrived in Kearsney, he organised a prayer meeting with the expressed purpose to establish a church there. The result of this prayer was the establishment of the first Telugu Baptist Church in Africa (Rangiah 1953:14). In Natal, prayer continued to feature strongly in Rangiah's ministry. In 1906, Rangiah prayed for the outpouring of the Holy Spirit (Rangiah 1953:17). He maintained that prayer was necessary for personal cleansing. At a prayer meeting that took place in 1906, congregants wept and cried aloud. They prayed for mercy and forgiveness. It was reported that these prayer meetings were held over a period of four months. In Nonoti, a hill (which was named Prayer Hill) was a place Rangiah and others used for prayer (Rangiah 1953:17). Rangiah also initiated home prayer meetings (Rangiah 1953:21). He wrote that he and his wife prayed earnestly for buildings for places of worship, and he gave thanks to God for providing them with buildings in places like Stanger and Verulam. In his second and third reports he lists the number of pastors that he appointed to the churches and the churches' financial support of those pastors despite the economic status they were in. He wrote, 'We are trying hard to help ourselves, and when we do our part, we know the Lord will care for the rest' (Rangiah 1953:21). Rangiah recognised the impact of prayer regarding education for the poor Telugus. He established a school in Kearsney; here the influence of the American Baptists in India influenced his theology on education. In their work in India, American Baptist missionaries shared the Christian faith with the Telugus and contributed to the educational advancement and social uplifting of these people by building schools and hospitals. Mimosthram Rangiah (1953:16) recorded that as a missionary, John Rangiah was responsible not only for the spiritual needs of the Indians in Natal, but also for the educational requirements of the many Indian children who were growing up illiterate. He once again presented this need to God in prayer. It is recorded that he went on his knees and asked for God's guidance and help in that matter. In answer to his prayer, his landlords, the Huletts, provided an old laundry building for this purpose. On Monday, 10 October 1904, the first Indian school in Kearsney, South Africa, was opened. Four pupils were in attendance. By the end of that year, the enrolment had increased to 12 (Rangiah 1953:16).

\section{Salvation}

It seems from Rangiah's letterhead that his call to South Africa was based on Isaiah 61:1. Although it is difficult to base one's theology on this verse, such a text, without any exegesis, is insufficient for anyone to do any meaningful analysis. Nevertheless, it conveys the idea that Rangiah was driven by this call to preach salvation.

Furthermore, Rangiah's hymn entitled "New Birth" (Rangiah 1890) reflects this theme of salvation. In an interview with Vijay Ramanjulu on July 2010, the English translation is as follows:

Chorus:

The great teacher Jesus Christ confirmed that man should be born again in order to enter into heaven 
Nicodemus the leader of the Jews who knew the law was thinking of Jesus

He went at night to the Lord, stood before him and talks to him in peace.

Rabbi, you are teaching about the word of the Lord of heaven and we understand it.

And the signs (works) of God that you do, cannot be done by ungodly men

As the Pharisees said these things Jesus replied to him with grace and mercy

Jesus told him the truth that none can be lifted up to the Kingdom of heaven without the new birth.

The Pharisees asked how an old man can enter his mother's womb to be born again.

Then Jesus said unless you are born of the spirit you cannot enter into the Kingdom of God.

Rangiah's hymn is based on John 3:1-21. Protestant Christianity understands salvation to be grounded in the life, death and resurrection of Jesus Christ. The result of the death, burial and resurrection of Christ is redemption (McGrath 2001:407). It is at this point that a person experiences a new life. There are many instances in Rangiah's ministry which reflected aspects of salvation.

It does appear that Rangiah believed in the universal saving will of God and that salvation is possible only in and through Christ. His ministry to the prisoner in Durban displayed this. Rangiah invited the prisoner to make a choice to either accept or reject salvation. The condemned chose salvation (Rangiah 1905:1).

From an evangelical perspective, Rangiah fits into a model that salvation is personal only. There is debate amongst many evangelicals on the definition of salvation as it relates to evangelism. Sider (1993:85-91) argues that the definition of salvation is crucial in one's understanding of the relationship between evangelism and social concern. Using both the Old and New Testament he shows how salvation is both individual and communal as well as corporate by citing texts such as Hosea 1-7, Ezekiel 43:1, Exodus 14:30 (corporate salvation) and Mark 10:17-26, Luke 19:19 (individual salvation), Luke 17:19 (individual salvation) and Ephesians 2:11-3:7 (corporate salvation), to name just a few. On the other had, there are evangelicals such as Billy Graham who would argue that salvation is only personal. Sider's definition that it is personal, corporate and communal has merit. There is substantive evidence in both the Old and New Testaments that support this. Some Baptists think otherwise. Rangiah seems to be amongst this group.

\section{Eschatological hope}

Rangiah, in a hymn entitled "The Door to Heaven" (Rangiah 1890), wrote about the hope. The English translation of this hymn is as follows:

\section{Chorus:}

Jesus is the beautiful door-the beautiful door-on the way to heaven.

He is the beautiful door through which you enter into the land of Cannan where the milk and honey flow

$\mathrm{He}$ is the beautiful door through which people enter into the
Holy place of the temple in Jerusalem.

He is the beautiful door through which we enter into heaven as the priest of the holy of the holiest

He is the beautiful door which is the right door even though it is narrow, it leads us to happiness in spite of troubles

Craig Keener stated in an interview on July 10, 2010 that this hymn reflects a Johannine imagery (eschatology) which is at the very least a very standard evangelical theology. Eschatology in the Christian tradition comes from the Greek term ta eschata [the last things] and relates to such matters as the Christian expectations of Christ's resurrection and judgement (McGrath 2001:553). It appears that Rangiah, through this hymn, was presenting hope to the indentured labourers in the midst of suffering. Craig Keener also stated that it is precarious to extrapolate from Rangiah's hymn any meaning without an understanding of his social context. We do know through the writings of Dhupelia-Mesthrie (2000:918) that indentured labourers suffered. On the other hand, there is no record of Rangiah addressing these sufferings; he does, however, through the medium of this hymn and although written in 1890, provide hope to the indentured labourers in the midst of their suffering.

\section{Post-colonial hermeneutic}

The landscape of Christian theology is expanding with many emerging theologies coming from non-Western cultures that were previously colonised. These non-Western theologies are challenging some of the suppositions of Western theology. One such theology is postcolonial theology. Postcolonial theology applies insights of a discourse of post-colonial theory. It examines the continued impact of European colonisation on societies and cultures that were previously colonised. This theory addresses issues of race, gender, identity, globalisation and power relations (Dyrness \& Karkkainen 2008:683). Postcolonial biblical hermeneutics is the lens through which one reads the biblical text. It is read from an oppositional position. It is a form of resistance discourse from the margins which self-consciously confronts and critiques colonial ideology and its underlying assumptions. This type of discourse did not take place amongst Baptists in South Africa. If it did, it was mainly amongst the colonisers and not by those in the margins.

Loida Martell-Otero, a Puerto Rican veterinarian turned theologian, described how she examined animals such as a cat. She would run her fingers beginning at the rear of the animal all the way to the neck. In this way she could more easily detect if there were any lumps that may be cancerous. In an interview with Martell-Otero on January 2010, she stated that the conventional method of examination is to run the fingers along the direction of the hair or fur (This metaphor aptly describes how post-colonial hermeneutics approach the interpretation of scripture. Although it takes into consideration the conventional grammatical-historical method, it also goes against the grain and when it does find 'lumps' it asks serious questions about them and attempts to make the application to the present context. These lumps often represent oppressive systems which when taken into 
account can offer a less biased interpretation. There are not many writings and sermons of Rangiah. Many of them are recorded in Telugu in his personal diaries which are not accessible. However, the few available writings (such as his hymns) give some perspective on how he read and interpreted the Bible.

Rangiah's emphasis on prayer seems to focus mainly on his ministry and not on the socio-political realities of his time. On the other hand, Mohandas K. Gandhi who came to South Africa in 1893 addressed discriminatory laws that affected Indians. His experience in South Africa did not deter him from championing the cause of Indians in South Africa. When the Colonial government began tightening its grip on Indians, Gandhi, together with the Natal Indian Congress, engaged in protests. Their resistance was termed 'satyagraha', which meant 'the force which is born of Truth and Love or non-violence' (Dhupelia-Mesthrie 2000:21). Nowhere in Rangiah's writings does he refer to his social context.

Generally conservative evangelicals do not focus much on socio-political issues. Rangiah's treatment of salvation, which focused on the individual's spiritual state without reference to the physical condition, reflects such an orientation. Scripture uses the word 'salvation' mainly in the sense of liberation of the human race or individual person from sin and its consequences. The consequences of an unjust system in South Africa during the period Rangiah served as missionary are not mentioned in his sermons or hymns. Yet the indentured labourers became part of this system. Salvation involves the whole person including his or her situation because the Bible is also about oppressed, enslaved or marginalised people. In this way theology enables people to claim scripture for themselves and shows that it relates to the whole person's situation and practical needs so the Christian community should acknowledge this as part of salvation.

Rangiah's comments on the eschatological hope in John 2, where he speaks of hope in a highly spiritually sense without reference to the contextual reality of his time, also evidences a traditional interpretation of the text. Given the sociopolitical context of that time where oppressive laws impeded the full development of the Indian indentured labourers, it was important to integrate his understanding of the text with those realities thereby allowing his audience a sense that the Bible speaks to their situation.

\section{Conclusion}

I have examined Rangiah's understanding of the Bible and Bible themes and how they impacted his ministry in Natal. I found that he brought with him his understanding of Christian ministry from his country to his work in Natal which focused mainly on the indentured labourers and their cultural and spiritual needs.

In analysing the impact of the Bible and Bible themes on John Rangiah's ministry in South Africa, it seems like he reflected a moderate evangelical orientation and held strongly to the
Baptist tradition of biblical authority. He took seriously the biblical view regarding the importance of prayer, salvation and eschatological hope.

Rangiah also reflected the Baptist tradition of engaging in missions. His thinking and action is consistent with a worldview that the church should be missional in its outlook. His arrival as a missionary in South Africa saw him work exclusively with the Indian population with no record of him engaging African people; language and culture must have posed as barriers.

Rangiah advanced a model that did not fully address the social needs of the Telugu indentured labourers. If he did, they are not reflected in his sermons and ministry reports. There is one ministry project, the opening of a School in Kearsney, which Rangiah initiated, that met the educational needs of his congregants. Rangiah was loyal to his Baptist tradition regarding his understanding of salvation which has a direct implication on evangelism. If he embraced an understanding that salvation was personal, corporate and communal, then he would be embracing an ecumenical model with an emphasis falling heavily on the social. Rangiah should have embraced both these models. Addressing personal sin and structural sin was important given the spiritual and social state the indentured labourers found themselves in.

Rangiah was a missionary and not a biblical scholar who was trained and influenced by American Baptist missionaries in India. It seemed he was not exposed to the knowledge we now have with regard to post-colonial perspectives. Therefore it is not entirely fair to criticise his theology as a biblical scholar. As a missionary, his work amongst the indentured labourers is noteworthy given the fact that he represented a person of colour; this was not common in the early 20th century.

The fact that Rangiah represented an indigenous mission agency and dared to venture into a foreign country to engage in mission work is noteworthy and is an example to Indian Baptists that foreign missions by Indians is possible and should be encouraged. His work continues amongst Indians and the organisation he established in 1914. This organisation, The Baptist Association of South Africa, will celebrate its centenary in 2014. Rangiah laid a foundation for the Indian Baptists in South Africa to build upon. It is important that Indian Baptists engage Rangiah's work by evaluating it in the light of the new realities in South Africa.

\section{Acknowledgements Competing interests}

The author declares that he has no financial or personal relationship(s) which may have inappropriately influenced him in writing this article.

\section{References}

About the Baptist World Alliance, 2010, 'BWA member Body Statistics', viewed 28 October 2010, from http://www.bwanet.org/aboutbwa

American Baptist Church, USA, 2009, Who we are?, viewed 19 February 2009, from http://www.abc-usa.org/whoweare/vision/vision.aspx 
Birch, W., 2008, The Sovereignty of God and Humanity, viewed 02 March 2011, from http://www.evangelicalarminians.org/node/78

Baptist Principles, 2009, The coalition for Baptist Principles, viewed 21 September 2011, from http://www.baptistprinciples.org/declaration.htm

Dhupelia-Mesthrie, U., 2000, From cane fields to freedom: A chronicle of Indian South African life, Kwela Books, Cape Town.

Dyrness, W.A. \& Karkkainen, V-M., 2008, Global dictionary of theology, Inter-Varsity Press, Nottingham.

Elphick, R. \& Davenport, R., 1997, Christianity in South Africa: A political, social and cultural history, James Currey, Oxford.

Jewett, F., 1898, Leaves from the Life of Lyman Jewett, Philadelphia: American Baptist Publication Society.

Jewett, L., 1913, John Rangiah, The First Telugu Foreign Missionary, American Baptist Foreign Mission Society, Boston.

Gutierrez, G., 1974, A theology of liberation, SCM, London.

Hudson-Reed, S., 1983, By taking heed, Baptist Publishing House, Roodepoort.

Israel, N.M., 1988, Indian Baptist History, BASA Annual Brochure, Victory Printers, Stanger.

Israel, N.M., 2004, 'John Rangiah and a Century of Indian Baptist Work in Africa (1903-2003)', speech delivered to Baptist World Alliance Heritage and Identity Commission, Seoul, Korea, Washington, VA.

Jacob, V.C. \& Cornelius, H., 1953, The Indian Baptist Mission: 1903-1953, CP Press, Durban.

Marger, M.M., 2003, Race and ethnic relations: American and global perspectives, Thomson Wadsworth, CA.

McGrath, A., 2001, Christian theology: An introduction, Blackwell Publishing, Oxford.

Members and Partners, 2009, American Baptist Churches, viewed 29 February 2009, from http://www.faithstreams.com/topics/members-and-partners/americanbaptist-churches-usa.html
Moses, K.D., 1978, Indian Baptist Mission Diamond Jubilee, 1903-1978, brochure, Colortel Press, Durban.

Olson, R., 1998, Christianity Today: Does Evangelical Theology have a future today?, viewed 02 March 2009, from http://www.ctlibrary.com/ct/1998/ february9/8t2040.html

Rangiah, J., 1890, Telugu Hymns, NM Israel Collection, NM Archives, Tongaat, KwaZulu-Natal.

Rangiah, J., 1905, The first and second annual reports of the Telugu Baptist Mission, Natal, South Africa, First Missionary to the Telugus in Natal, M.E. Press, Madras.

Rangiah, J., 1905, The Telugu Mission in South Africa, American Baptist Historical Society, Africa, The American Baptist Historical Society, Valley Forge.

Rangiah, J., 1907, The third annual report of the Telugu Baptist Mission, Natal, South Africa, American Baptist Historical Society, Orissa Press, Cuttack.

Rangiah, M., 1953, NIBA News, Mercantile Printing Works, Durban.

Rowland, C. (ed.), 1999, The Cambridge companion to liberation theology, CUP, Cambridge.

Sider, R., 1993, Good news and good works: A theology for the whole gospel, Baker Books, Grand Rapids.

Sider, R., 2008, The scandal of evangelical politics: Why are Christians missing the chance to really change the world, Baker Books, Grand Rapids.

Stanley, B., 2009, The World Missionary Conference: Edinburgh 1910, William B. Eerdmans Publishing Company, Grand Rapids/Cambridge.

Sugirtharajah, R.S., 1998, Asian biblical hermeneutics and post-colonialism: Contesting the interpretations, Orbis Books, New York.

Swamy, R., 1999, The Baptist Association of South Africa, brochure, Victory Printers c.c., Stanger.

Timothy, N. Risecliff, 1976, Baptist Church, Silver Jubilee of Rev. D.N. Nathaniel's Witness in South Africa, 1951-1976, brochure, Baptist Church, South Africa.

Timothy, N., 1978, The diamond jubilee of the Indian baptist work in South Africa 1903-1978, Victory Printers, Stanger. 